\title{
Sustainable Ship Recycling Methods and Process for Global Major Ship Recycling Players
}

\author{
Khandakar Akhter Hossain* \\ Department of Naval Architecture and Marine Engineering, Bangladesh University of Engineering \& Technology, Bangladesh
}

Submission: September 25, 2018; Published: November 15, 2018

*Corresponding author: Khandakar Akhter Hossain, Department of Naval Architecture and Marine Engineering, Bangladesh University of Engineering \& Technology, Bangladesh

\section{Opinion}

The world-wide ship recycling industry dismantles around 1,000 large ocean-going vessels per year, such as container ships, cargo \& bulkers, oil \& gas tankers (LNG, LPG), passenger ships and other types of ships, to recover steel and other valuable metals or recyclable items[1]. However, at present almost all ship recycling activities are concentrated in five countries: the three South East Asian countries (India, Bangladesh, and Pakistan), China, and Turkey[2]. Further capacity is available in North America (US, Canada, Mexico) and within the European Union (amongst others Denmark, Belgium and UK). At present, South East Asia is undoubtedly the global center for ship recycling activities.South East Asia contributes to more than ninety percent of global ship recycling activities[3]. Countries such as Pakistan, India, Bangladesh and China are the major ship recycling player and centers of the world.

It can be concluded from method of recycling that beachbased ship recycling method is being followed in all the major ship recycling countries except China[4]. Ship recycling becomes economically viable in the developing countries only when the actual operations are carried out in beaches. There are number of guidelines in ship recycling which, when applied to the respective fields would improve the status of the industry as safe and environment friendly[5]. Considering these two observations, both operations in beach-based activities and guidelines, a set of viable roles and procedures for the industry can be formulated. If these viable roles and procedures are implemented through a user-friendly knowledgebase system, it is possible for useful, competent and viable ship recycling by applying beaching method[6].

The recycling of end-of-life vessels in an environmentally friendly and safe manner has been a major challenge faced by ship owners and ship recycling facilities in recent years and it is not a subject that will subside any time soon[7]. In fact, it is estimated that as of today, globally around 20,000 ships over 500 Gross Tonnage are more than 23 years old and will soon be sent for recycling. There are various reasons why an owner may choose to recycle a ship: due to its increasing age, an uneconomic cost of repair, the current oversupply in the market, specific regulatory requirements such as double-hull specifications for tankers or very occasionally due to the introduction of innovative technology and important changes to trading patterns[8]. On an average, vessels tend to go for recycling at around 25 years; however, this can be a few years later if they are on long charters, or earlier in periods of economic recession with fewer charters available, as we are seeing at present(Figure 1).

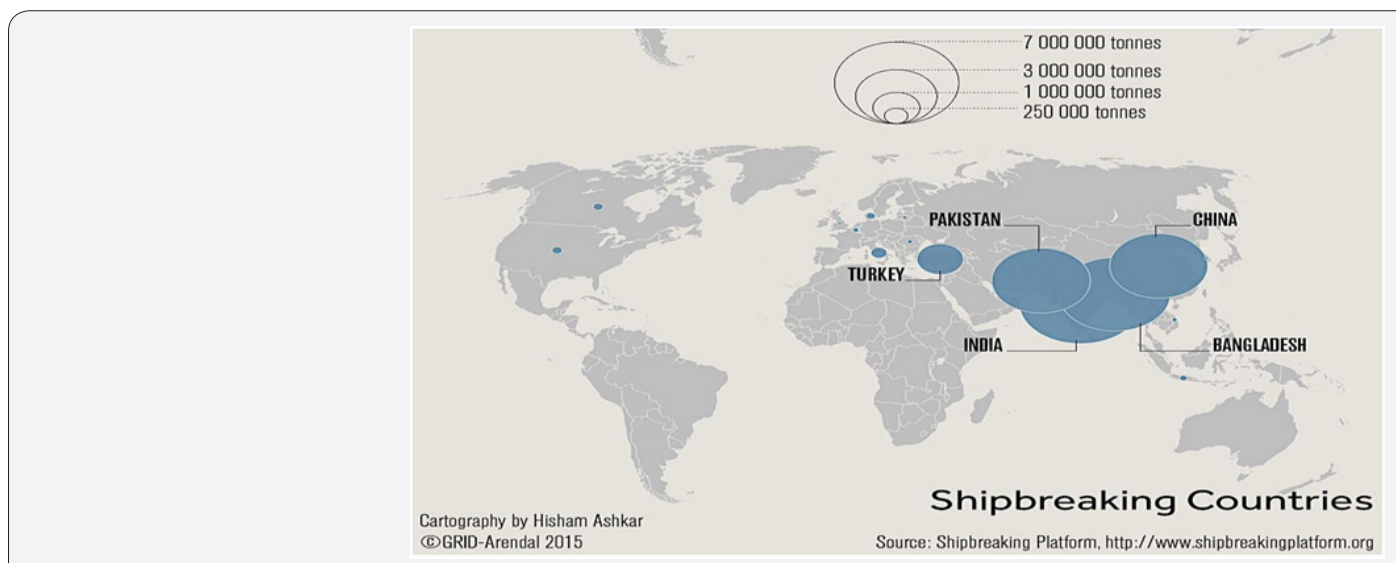

Figure 1: Ship recycling Countries as stated on Ship-breaking Platform Related to Ship Recycling Process. 
For the last twenty-three years, ship recycling yards in Bangladesh, China, India, Pakistan and Turkey have been recycling $97 \%$ to $98 \%$ of all the recycled tonnage in the world[9]. In Bangladesh, average 200 different types of obsolete ships are recycled annually in different yards located in Chottogram. Again, from on ground statistics of ship recycling yards of Bangladesh, we can see that, average 2000000 LDT different types of EOL ships are recycled annually in different yards in Bangladesh. In Figure 2 below, total LDT of different types and size of ships recycled and usable material output in Bangladeshi yards has been shown. Bangladeshi recycling yards are dismantling around $25 \%$ of global EOL ships[10]. The general and exclusive data, analysis, result, graph and output has been described elaborately in detail in my Ph D research work. However, the increase in demand for ship recycling has rightly led to an increase in regulatory pressure at both national and international levels[11]. This regulatory pressure resulted in the development of the Hong Kong International Convention for the Safe and Environmentally Sound Recycling of Ships (HKC) by IMO in 2009, to mandate safety and environmental protection standards at yards. Although discussions are at an advanced stage, the HKC has not been ratified yet by most of the countries involved[12]. This means that for the time being, the growth of responsible ship recycling is reliant on market dynamics between ship owners and recycling yards. However, the scrutiny that the development of the HKC brought to the yards has been driving change. The shipping industry has become increasingly aware of its responsibility to improve its sustainability and the ship recycling industry has been developing its best practices accordingly.

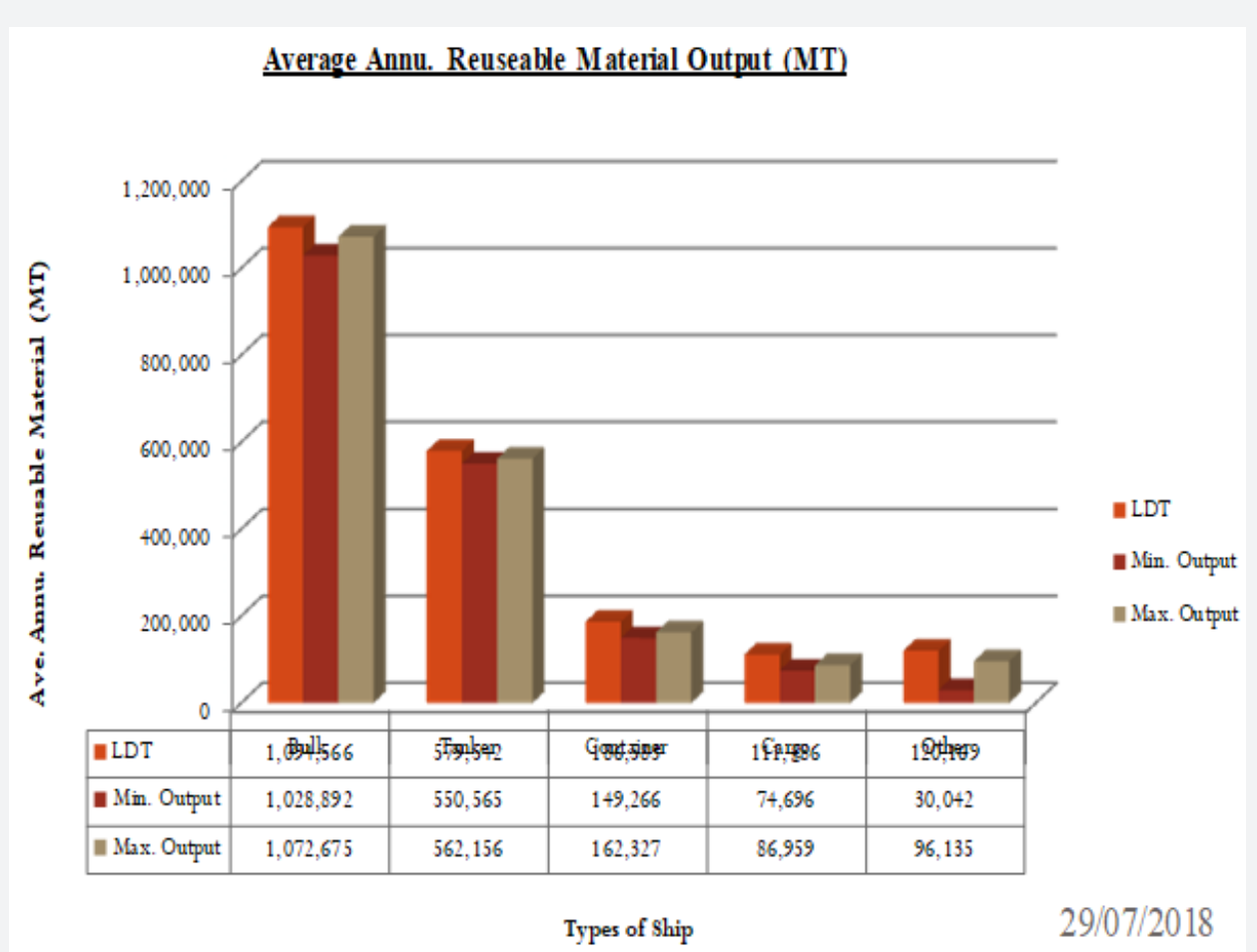

Figure 2: Average annual LDT recycled and reusable material output in Bangladeshi yards.

The demand for responsible ship recycling now exceeds supply in South Asia. Yards that have invested in achieving the standards of the HKC are now seeing growth in demand for their services based on the good health, safety and environmental practices they follow. This has in turn incentivized other yards to improve their own standards and consider ISO and OHSAS and HKC Statements of Compliance (SoC) Certifications. But the key question remains, what does "option for viable green ship recycle" in the ship recycling industry look like? It is needless to emphasize that recycling is the sustainable option for handling end-of-life vessels. When we look for "option for viable green ship recycling" in recycling, it means recycling activity with viable available techniques and viable environmentally friendly practices in use. In other words, option for viable green ship recycling is the systematic prevention and the mitigation of safety and environmental risks at yard facilities, in procedures and operations, supported by preparatory work by the ship owners, flag states and classification societies[13]. The standards of the HKC and its guidelines are designed to reflect this best-practice approach in ship recycling and although it is yet to enter into force, it defines the basis of what we mean when we talk about responsible ship recycling. Therefore, responsible ship recycling starts when both the ship owner and the recycling yard comply with the standards and guidelines of the HKC. 
Major ship recycling player need to develop an environmentally friendly and sound ship recycling plan (SRP) and provide advanced training to their local yards in areas such as: the handling of hazardous wastes/materials, working in confined spaces and at heights, fire prevention and control, use of proper protective equipment (PPE), cutting and removing paint from plate on hard standing floor, adequate and safe rest recreation shower and accommodation facility for worker, emergency evacuations and rescue plans, safe handling, inventory and storing of hazardous waste, preventive environmental practices through environmental awareness in regular basis, make viable plan for worker good health, welfare and future, employ naval architect and technical personal in every recycling yards, ensure regular training and updated worker knowledge about modern technology and regulations.

The yards and company need to be produced IHM reports with proper guidance and supervision by respective ministry and academic bodies and in collaboration with the ship-owners, for the identification, removal and safe disposal of hazardous materials[14]. Moreover, an HKC-compliant ship recycling yard will produce a Ship Recycling Facility Plan (SRFP), documenting the yard's systems, facilities and processes to ensure safety and environmental protection. Each recycling project is then planned out in advance and managed according to an individual and specific Ship Recycling Plan (SRP). The SRP is developed by the yard management under the guidance of GMS Green Team, using the SRFP, design of the vessel and its Inventory of Hazardous Materials to plan a safe and environmentally friendly recycling sequence. The GMS Green Team along with the yard management also develop and implement a system of standard operating procedures for each work activity practiced during the recycling of vessel: from beaching to complete recycling, including the safe removal and temporary storage of hazardous wastes with proper training on PPE and recycling yards activates, emergency evacuations and rescue process, safe handling, inventory and storing of hazardous waste and so on. Some of South Asian recycling yards from all three major players are already achieved such standard.

This work is licensed under Creative Commons Attribution 4.0 License DOI: 10.19080/OAJT.2018.03.555622

\section{References}

1. Hossain KA (2015) Overview of Ship Recycling Industry of Bangladesh. Journal of Environmental and Analytical Toxicology 5(5).

2. Hossain KA, Zakaria NMG, Iqbal KS (2010) Ship Recycling Prospects in Bangladesh. Proceeding of MARTEC 2010; International Conference of Marine Technology, BUET, Dhaka, Bangladesh.

3. Hossain KA, Iqbal KS, Zakaria NMG (2010) A Study of Socio Economic and Ecological Impact of Ship Recycling in Bangladesh. The Journal of NOAMI 27(1): 35-47.

4. Hossain KA (2017) Ship recycling practice and annual reusable material output from Bangladesh ship recycling industry. Journal of fundamentals of renewable energy and application 7(5).

5. Hossain KA, Zakaria NMG, Islam MS (2010) SWOT analysis of shipbuilding industries in Bangladesh and its challenges to become potential ship exporting nation. Journal of Ship Technology India 6(2).

6. Hossain KA, Zakaria NMG, Rahman MM (2010) Study on some competitive parameters for shipbuilding industry in Bangladesh, International Conference on Marine Technology: MARTEC 2010 Proceedings.

7. Hossain KA, Zakaria NMG, Islam MS, Iqbal KS (2010) A study of socioeconomy and ecological impacts of ship recycling in Bangladesh. The Journal of NOAMI 7(1).

8. Hossain KA, Zakaria NMG (2009) Service provides and supporting industries of shipbuilding sector on Bangladesh and its impact on overall development of shipbuilding, Proceedings of the $6^{\text {th }}$ International Conference \& $13^{\text {th }}$ Annual Paper Meet, Dhaka, Mechanical Engineering Division; The Institute of Engineers, Bangladesh (IEB).

9. Hossain KA, Zakaria NMG (2012) Underlying Problems of shiprecycling industry in Bangladesh and way forward, $6^{\text {th }}$ International Mechanical Engineering Conference \& $14^{\text {th }}$ Annual Paper Meet.

10. Hossain KA (2015) Future of Energy Resources. International Journal of Renewable Energy Technology Research 4(5).

11. Hossain KA (2015) Leadership Qualities for $21^{\text {st }}$ century Leaders. Journal of Management, Social Science and Humanistic 1(2).

12. Hossain KA (2015) Essential Tips and Tactics of motivation. Journal of Management, Social Science and Humanistic 1(1).

13. Hossain KA (2018) SWOT Analysis of China Shipbuilding Industry in the Third Eyes. Journal of recent advancement of petrochemical science 4(2).

14. Hossain KA (2018) Calculation of Yearly output of reusable material of Ship Recycling Industry of Bangladesh. Journal of Recent Advancement of Petrochemical Science 5(3).

\section{Your next submission with Juniper Publishers will reach you the below assets}

- Quality Editorial service

- Swift Peer Review

- Reprints availability

- E-prints Service

- Manuscript Podcast for convenient understanding

- Global attainment for your research

- Manuscript accessibility in different formats

( Pdf, E-pub, Full Text, Audio)

- Unceasing customer service

Track the below URL for one-step submission https://juniperpublishers.com/online-submission.php 